Case Report

\title{
Anonychia Congenita in a Young Boy - A Rare Entity
}

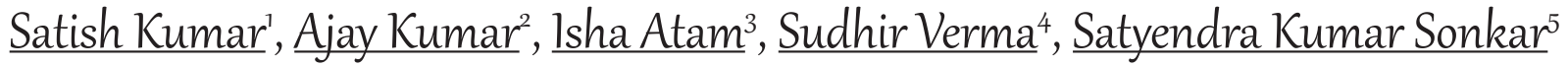 \\ ${ }^{1}$ Senior Resident, Department of Endocrinology, King George's Medical University, Lucknow, India. \\ ${ }^{2}$ Additional Professor, ${ }^{5}$ Professor, Department of Medicine, King George's Medical University, Lucknow, India. \\ ${ }^{4}$ Associate Professor, ${ }^{3} \mathrm{MBBS}$, King George's Medical University, Lucknow, India. \\ DOI: https://doi.org/10.24321/2349.7181.202007
}

\section{I $\quad \mathbf{N} \quad \mathbf{F} \quad \mathbf{O}$}

\section{Corresponding Author:}

Satish Kumar, Department of Endocrinology, King George's Medical University, Lucknow, India.

E-mail Id:

dr.satishkgmu@gmail.com

Orcid Id:

https://orcid.org/0000-0002-6691-4281

How to cite this article:

Kumar S, Kumar A, Atam I, Verma S, Sonkar SK. Anonychia Congenita in a Young Boy - A Rare Entity. J Adv Res Med 2020; 7(1): 20-22.

Date of Submission: 2020-10-12

Date of Acceptance: 2020-10-26

\section{$\begin{array}{llllllll}\mathbf{A} & \mathbf{B} & \mathbf{S} & \mathbf{T} & \mathbf{R} & \mathbf{A} & \mathbf{C} & \mathbf{T}\end{array}$}

Congenital anonychia in isolated form is a rare anomaly in which there is absence of nails of fingers and toes since birth. Other ectodermal and mesodermal defects in the body are absent. Here, we report a case of 16 year old male having rare congenital disorder anonychia in his hands and feet except in little finger of right hand, lateral two digits of right foot and thumbs of both hands with deformed nails. All other systemic examinations were normal. His parents and siblings were normal as were the second degree relatives.

Keywords: Anonychia, Congenital Anomaly, Autosomal Recessive

\section{Introduction}

Congenital simple anonychia is a rare anomaly in which there is absence of nails of some or all fingers and toes since birth without any association with other syndrome. ${ }^{1}$ Absent nails, anonychia, aplastic nails, congenital absence of nails and hyponychia congenita are the other names for this condition. Anonychia may be either acquired anonychia or congenital syndromic anonychia and both are more common than congenital asyndromic type. ${ }^{2}$ Simple congenital anonychia, denotes congenital absence of the nails where there is no other congenital defect. This is an extremely rare type of anonychia. Autosomal recessive inheritance is the main mode of inheritance in simple anonychia. $^{3}$

In hyponychia only a part of the nail is missing and other tissues at the tips of the fingers and toes, such as nail bed are normal. Other than anonychia congenita overall health of the patient remains normal. Its prevalence is unknown.

The etiology behind this rarest condition is mutations in the RSPO4 gene on chromosome 20 in exon $3 .{ }^{4}$ Fragility on the long arm of the chromosome 10 is also associated with the anonychia. ${ }^{5}$ This gene gives instructions for synthesis of a protein called R-spondin-4. R-spondin-4 have an important action in the Wnt signaling pathway, which is responsible for growth and development of nails. ${ }^{5}$ As a result of nonavailability of facilities, chromosomal studies and gene mapping studies were not possible. ${ }^{3}$

\section{Case Report}

A16-year old male presented to our outdoor clinic with chief complaint of absence of nails of all fingers (anonychia) of hands and feet except in little finger of right hand, lateral two digits of right foot and thumbs of both hands 
with deformed nails since birth. There was no history of any chronic illness or injury. His parents were normal. On examination he was conscious and oriented with stable vitals. IQ (Intelligent Quotient) was normal to age. Physical examinations revealed absence of finger nails and toenails except on the little finger of right hand. Nail folds, nail beds and distal phalanges were found normally developed. Tips of the involved fingers were soft and compressible but with normal function and intact sensations (Figure 1). Hairs, teeth, tongue, oral mucosa, and head circumference all were normal. Icthyosis, dyshidrosis, skin pigmentation, palmoplantar keratoderma, or mental retardation were not found. X-ray of chest, hands and feet were also normal. According to his parents he was born at home via normal vaginal delivery at full term. There was no history of intake of any medicine by the mother during pregnancy. His parents and brothers had normal nails. His day-to-day activities were never hampered by anonychia in any condition. Further investigations related to genetics could not be done due to financial constraint.

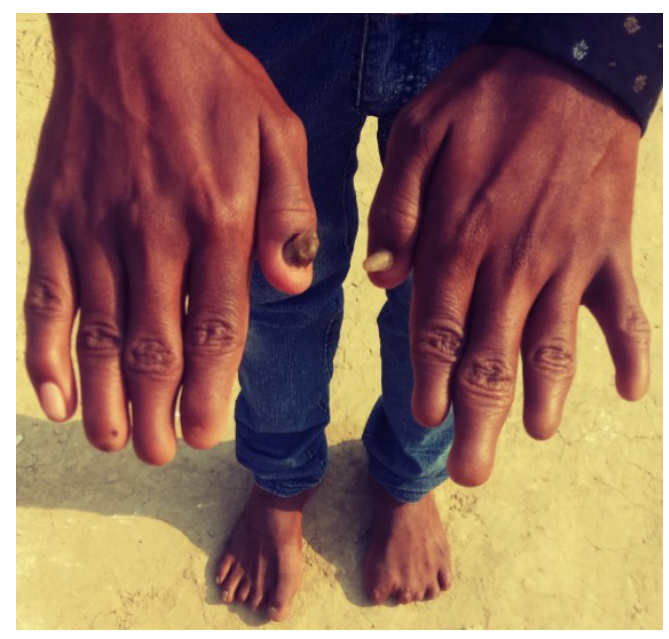

Figure I. Absence of nails of toes and fingers in all four limbs

There is no treatment for congenital anonychia. Masterly inactivity is the only thing required in such cases.

\section{Discussion}

Anonychia, a rare anomaly, may be congenital or acquired. At gestational age of 8-10 weeks development of nails starts

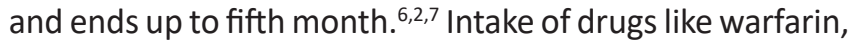
phenytoin and alcohols by the pregnant mother during first and second trimester leads to nail anomalies. ${ }^{8}$ Viral infection during the same period also causes nail anomalies. ${ }^{3}$ In this case, pregnancy of mother was normal without any history of medication intake.

Common etiologies for acquired anonychia includes epidermolysis bullosa, pemphigus, lichen planus, trauma and Stevens-Johnson syndrome. , $^{2}$ Important congenital causes includes various syndromes like nail-patella syndrome,
AEC syndrome (ankyloblepharon, ectodermal defects, cleft lip/palate), TOOD syndrome (tricho-odonto-onychodermal), DOOR syndrome (deafness, onychodystrophy, osteodystrophy and mental retardation), EEC syndrome (ectodactyly, ectodermal dysplasia, cleft lip/palate), hypohidrotic ectodermal dysplasia including multiple anomalies and craniofacial malformation syndromes. ${ }^{3}$

Inheritance of embriopathic nail diseases occurs while fetopathic disorders not inherited etiology of which may be mechanical or vascular disturbances in uterine life. ${ }^{9}$ Normal nail formation occurs on underlying bone and anonychia or hyponychia may develop in case of either hypoplastic or completely absent terminal phalynx. ${ }^{10}$ In simple anonychia, there is absence of nails since birth while no any coexisting anomaly is found. Among nail disorders isolated simple anonychia is an extremely rare condition. Autosomal recessive pattern is the main mode of inheritance. ${ }^{3}$ In this case parents and other family members were not affected probably this case is recessive in inheritance.

To reduce the chances of recessive characters like anonychia, matrimony between closely related individuals (consanguineous marriage) should be avoided. Iran, Saudi Arabia, Turkey, India and Kazakhstan have consanguineous marriage trends, as a result of which total or near total simple anonychia with AR inheritance pattern are reported. ${ }^{1,11-13}$

\section{Acknowledgement: None \\ Conflict of Interest: None \\ References}

1. Afsar FS, Karakuzu A. Total congenital anonychia. Pediatr Dermatol 2014; 31: 743-744.

2. Yadalla HKK, Nitya R, Sujatha C. A rare case of isolated congenital complete simple anonychia. Int J Health Allied Scien 2012; 1: 32-33.

3. Yadalla HK, Nitya R, Sujatha C. A rare case of isolated congenital complete simple anonychia. International Journal of Health \& Allied Sciences 2012; 1(1): 32.

4. Bruchle NO, Frank J, Frank V, Senderek J, Akar A, Koc E. RSPO4 is the major gene in autosomal-recessive anonychia and mutations cluster in the furin-like cysteine-rich domains of the Wntsignaling ligand R-spondin 4. J InvDermatol 2008; 128: 791-796.

5. Ozyazgan I, Ozyazgan I, Dundar M. Isolated congenital anonychia cases with coincident chromosomal fragility. Ann Gen 2004; 47: 381-386.

6. Samman PD. The nails. In: Rook A, Wilkinson DS, Ebling FJG, editors. Text Book of dermatology. 3 rd ed. New Delhi: CBS Publishers; 1986; 1823-55.

7. Al Hawsawi K, Al Aboud K, Alfadley A, Al Aboud D. Anonychiacongenitatotalis: a case report and review of the literature. Int J Dermatol 2002; 4: 397-399.

8. Lawry M, Daniel CR. Nails in systemic disease. In: 
Scher RK, Daniel CR, editors. Nails: Diagnosis, Therapy, Surgery. 3 rd ed. Philidelphia: Elsevier Science Limited; 2005; 147-169.

9. Telfer NR, Barth JH, Dawber RPR. Congenital and hereditary nail dystrophies-an embryological approach to classification. Clinical and Experimental Dermatology 1988; 13: 160-163.

10. Cynthia AL, Tamakoss D. Embryology. In: Bolognia JL, Jorizzo JL, Rapini RP, editors. Dermatology. 2 nd ed. India: Mosby Elsevier; 2008; 37-47.

11. Qureshi A, Wong KY, Grant I. Congenital anonychia. J Hand Surg Eur 2016; 41: 348-349.

12. Balta I, Kalkan G. A case report on autosomal recessive total congenital anonychia. Pediatr Dermatol 2013; 30: 268-269.

13. Al Aboud K, Al Aboud D. Autosomal recessive total congenital anonychia in saudia family. Our Dermatol Online 2013; 4: 496-497. 